\title{
Scales of Space, Place and Money
}

\author{
Discursive Landscapes of \\ Regional Inertia, Identity and Economical Change
}

\author{
INKA MORING
}

\begin{abstract}
A whole history remains to be written of spaces - which would be at the same time the history of powers - from the great strategies of geopolitics to the little tactics of the habitat. (Foucault 1980, 149)
\end{abstract}

During the years 1991-1996 the national economy of Finland literally crushed down. The crisis followed a long period of economic expansion, the boost that was more or less financed by international debts. In the beginning of the 90s, the Finnish economy entered a depression. Although this happened in many European countries, the Finnish case was among the most severe. The consequences of the crisis varied by region and sector due to structural differences in production and population within the country. As a consequence of the crisis the Finnish society faced a set of new problems in the 1990's: large scale long-term unemployment and social exclusion, and the crucial question of the sustainability of advanced welfare provisions.

It is not yet clear whether the regional disparities increased or how the inequality between regions developed. One thing is quite clear, however. Regionally there were variations in the scale and nature of strategies handling the crises. These variations appeared to be in relation to the reporting of the crisis in regional newspapers. Applied solely, a structurally conducted regional analysis would in this case be inadequate. Subtle meaning-making and interpretation processes of the situation also varied, forming specific regional media landscapes. The process could be studied from the point of view of different hermeneutical devices for understanding the situation. How was the collective consciousness of the people linked to the crisis, and how did this interact with the common characteristics of the region? And how did regional newspapers serve as mediators of ideological everyday practices linking economical events of the nation to the collective and cultural sphere of the people?

The fondled myth of 'Finnishness', the wholeness of the landscape of national identity remained as one layer of the symbolic structure. It was, however, contested by strong regional voices. National and regional, or local, identities were intertwined and created 'discursive landscapes', the conceptual compound attributed with a seemingly common contextual denominator - 'Finland' (see Häkli 1998,1). ${ }^{1}$ These discursive landscapes were, of course, in Foucauldian terms, tied to particular epistemes, practices and regimes - which were contingent and both spatially and temporally tied to specific conflicts and 
situations. There were both regional metabolism and inertia effecting the social change within regions.

\section{Spatial Perspective on Change}

The focus of my project has been the regional character of the crisis and its portrayal in regional newspapers ${ }^{2}$. The media coverage of the crisis in locally profiled newspapers is analyzed, asking how the 'stories' of the crisis were brought to the people in a regional setting, and what kind of journalistic strategies were applied in handling the issues. I also explore how the regional settings of everyday life construct textually as 'life worlds' in the newspapers. The main focus is on the relation between places and regions (different localities) and the process of identity construction (discursive regional and/or national frameworks in newspapers).

In the first phase of the research process the content of the news agendas of the regional press were examined quantitatively. ${ }^{3}$ The results of this analysis were striking. In the light of a broad categorization, the subject matters discussed in regional newspapers did not differ that much. But as soon as the analysis went beyond abstract categorizations, quite specific 'profiles' of local content were detected, constructed by the journalistic representation of each of the four regions. Issues like regional politics, employment, the center-periphery dimension and regional identity categories were differently represented. The qualitative analysis gave support to, and partly explained, the differences detected in the quantitative analysis. So, for example, some themes had crucial importance in regional 'life-worlds' when some issues did not matter as much. At the same time, in the light of regional statistics on GNP, the news agendas did not follow that either. For example, some regions continued to report bad news on regional economy when according to the regional statistics the regional economy had started to recover and also the other way round. Regional news-agendas constructed their own time-space.

During the time-span 1988-1997, also a transformation in orientation towards regional self-reflexivity occurred. This notion of reflexive nature of regional journalism was displayed in ways that revealed the growing interest towards regional characteristics as such. Partly this could be explained as economical, geographic and demographic structures that faced severe internal and external tensions and setbacks due to the recession $^{4}$. The most interesting explanatory factor was, however, the cultural or identity landscape. Was the variation in newspaper content and interpretation of the situation, the 'What is going on', due to regional cultural landscapes? And what kind of factor was this regional landscape? Was Finland entering from a Hegelian state domination to a Herderian Kulturnation, giving room for regional voices and putting up with growing differentiation (see Joenniemi 1998)?

An encounter of these matters requires notions on 'regional' and 'national' identity as concepts of explanation and historical containers. This article also leans on the conceptualization of discursive landscape(s). Discursive landscapes in this case are opened in the context of economic crises and social change the regions have faced. Local journalism is taken into the analysis as a hybrid form of ideologically tuned regionalist discourse with commercial and economical constraints.

Empirically, the focus of this article is on how mediated ideological (textual) practices have constructed spaces of economy and identity within one region, Northern Karelia. The local news agenda of the newspaper Karjalainen is analyzed in order to show how the 'crisis' was experienced in this specific discursive landscape. Here, the main question concerns the nature of those strategies and techniques that construct a 
'strong regional self (journalistically speaking) in a peripheral borderland area, e.g., how were scales of space, place and money created as discursive formations?

\section{National/Regional Identity as a Spatio-Temporal Container}

Space, place and landscape are central to any enterprise mapping and analyzing the geographic imagination of the nation. These concepts do not denote a fixed and static object, but ongoing processes within cultures. Spaces (regions, territories, areas etc.) as such are not a background to socio-historical actions. They could rather be seen as more vital products and determinants of those actions (Lefebvre 1991; Gregory 1986; 1994; Jarvis 1998; Paasi 1986). Following the definition of Gregory (1986, 451): "Space is not merely an arena in which social life unfolds but a medium through which social life is produced and reproduced." Space is always conceived, perceived and lived category (Lefebvre 1991).

Space/place/landscape are also inseparable from social relations and time. Geographical knowledge is impossible without taking historical narrative into account. Spaces and places contain stories and serve as palimpsests ${ }^{5}$ to specific contextual narratives of people. That is why space/place/landscape can be analyzed as sites of an ongoing struggle over meaning and value (Jarvis 1998). These concepts are represented as mental or textual constructions also in relation to the codes that are embedded in social power structures. From and within this spatial 'grid' or matrix of identities, also regional features are evolving as temporal containers within territories.

Usually, when we refer to regional or national identities, we are leaning on relational models of identity. These are formed by beliefs of common ancestry, or experience. They also give rise to shared characteristics or traits. In this case, identity can be defined as much by what we are as by who we are (Crang 1997). This is where geography and spatial dimension come into the picture, since these 'us' and 'them' are often territorially delimited groups and they need to be constructed with the help of the border(s). Relational identity models also have temporal dimensions. Anderson (1983) for example, in his work examining the rise of the nation and nation state, suggests that we have to regard 'national' identity as a historically specific form. For instance in feudal Europe, people did not use nation to frame their identity. National identity is something that has to be constructed in time and space. The maintenance of this symbolic construction needs also constant re-production with the help of cultural forms.

A short look into the Finnish historical past may give some clarity to this notion. A popular misconception is that Finns are a homogenous people who live within natural borders limited by the Baltic coast in the South and the West and with a political border in the East. Historical research, however, has shown that different types of Finnish communities and tribes existed in different parts of the Baltic area, connected by the sea that was their main communication road. At the same time, other Finnish communities were formed in the inner and northern parts of today's Finland, kept together by inner-sea routes, but isolated from the Baltic communities due to transportation difficulties over land. The historian Matti Klinge (1984: 10, 38-48) notes that the sharpest linguistic border within Finland between Finnish dialects nowadays remains between the coastal areas in the South-West of Finland and areas only some hundred kilometers farther east (Tavastland). ${ }^{6}$

There are different kinds of social and personal identities that may give shape to, and be formed by, cultural landscapes. National identity is a particular case of identities because it is usually formed with political aspirations (Gellner 1997; Hobsbawn 1992; 
Häkli 1998). The concept of national identity is problematic also when applied to analysis - because it usually implies national culture, as noted above - Finnishness (or Swedishness, Dutchness etc.) as an organic super-metaphor. Some central values of the group - collectivism, value of hard work, Lutheran ethic, and so forth - are assumed to apply, at least at some level, to each member of the nation. Furthermore, the national model usually tends to downplay the regional or individual human agency by focusing at the collective shaping of larger political entities. This vantage point reduces the comparative approach within one country with its tendency to flatten the cultural surface to one whole 'national discursive landscape'. Also the normative assessment of the current discussion depends very much on what parts of national culture or identities are in focus, and how and for what purpose these identities and cultural features are focused.

Regional identity as a concept puts emphasis on spatially delimited space or geographical surrounding, sense of place. The sense of place is based on the need to belong to the particular place, home, not to the society in the abstract sense. In satisfying this need of roots, people make commitments and develop loyalty to localities (Sennet 1999, 15). Modern place-making involves a search for the comforts of sameness in terms of shared identity and reduction of density. But place-making also needs a system that constantly allocates distinctions between us and them. Place-making as a form of expression has to be available to consumption in order to come a part of identity production, be it national, local or regional. It has to have a common and shared daily basis that is collective to its nature. Part of this regional identity production is based on symbolic stereotypes of different mental characteristics of the areas. They have been kept alive in the regional press (also in cultural and educational praxis) as part of ideology of everyday practice within imagined communities.

\section{What Is the Structure of the Imagined Community?}

The study of spatial dimensions of social life has quite often been considered theoretically problematic (Linz \& de Miguel 1966; Paasi 1986; 1991; 1997; Alexander et al. 1986; Harvey 1989; Soja 1989, 1996; Jameson 1992; Allen et al. 1998; Bird et. al 1993; Meyrowitz 1985). In recent human geography-oriented studies, some of these problems have been discussed and also partly elaborated focusing partly on the role of media (Haarni et al. 1997; Relph 1976; Thrift 1996; Bauman 1998) and by shifting the methodological emphasis towards a more qualitatively oriented analysis departing from a constructivist view. Media tends to replace as a technology and cultural phenomenon the missing link between individuals and institutions - communities and cultures. But, as a research object, is this phenomenon a cultural or structural enterprise?

The most difficult problems are connected with the questions how to tackle classical traps of both inductive and deductive explanatory models. To apply the problem to my analysis: how can we interpret the life-worlds that media products reflect without being guilty of obscuring cultural essentialism by finding 'regional' identity as an overall explanatory factor at the commercial, strategic and social levels? And, how can we modify explanations derived from purely structural factors (demographic, economical, geographical, etc.), at the same time avoiding ecological fallacies?

Anderson's (1983) conceptualization of the human capacity to create 'imagined communities' is one theoretical elaboration stemming from the constructivist vantage point. Any community in this sense is always imagined whether national, local or ethnic. Symbolic boundaries of language, culture and meaning-making process are essential in understanding that no area or territory is only a geographical site. It is always 
part of cultural understandings by those who inhabit the area.( Morley \& Robins 1995, 5). The concept 'imagined community' is also nowadays widely used in media studies (Meyrowitz 1985; Morley \& Robins 1995; Ekecrantz \& Olsson 1994). That is probably partly because it metaphorically circumvents the above mentioned theoretical problems. It replaces the classical dichotomy 'agency-structure' with imagination.

It is easy to see regional newspapers as analogous devices constructing textual spaces in which these 'imagined' human relations could take place. Speaking of 'community' means that relations between human beings are collective. Speaking of 'imaginary' in this case means that most of these relations are only imaginable but never actual. Most of the members taking part in this daily practice or 'ritual' of reading the newspaper never encounter their fellow-readers. Imagined community describes the orientation of an audience and this orientation is easier confirmed than contested.

Anyway, all the physical territory and regional structure - solid or not - does not melt into the air. Regional structures in economy and demography are more than imagined constraints of regional community. They are in an input relation to the newspapers as commercial enterprises. Journalists do possess - at least in some sense - the power of individual agency.

This is modified and supported by the professional and ethical codex of the profession. And, people constituting the audience do imagine and dream, as human beings tend to do, but they also live among political, economical and cultural structures - within borders that are more or less visible. The notion that people imagine and dream, also collectively, does not bring the process of analysis very far.

\section{Discursive Landscapes - Merging the Cultural and the Structural?}

We can also think that newspapers construct discursive landscapes. These context-sensitive landscapes are symbolic and textual webs of meanings and interpretations that frames the process of experiencing and understanding the living world. The discursive landscapes of the regions emerged with a broad range of cultural and political activities, events and projects, images and stereotypical flashes from the history producing the symbolic fabric linking the self-understanding of the people with a particular territory, concrete places and everyday practices and imagination. Regional cultures and spaces in this sense could be thought about in other ways than as bounded containers or as a background for imaginary practices (like national cultures; see Häkli 1998). They are processes where structures, representations of collective(s) and individuals change. And, as an explicit assumption, these 'discursive landscapes' are, at the same time, geographical, economical, textual and sociopolitical.

This conclusion is arrived at by coupling a term 'regional' (denoting collectivity of members of the community linked to each other, related to each other, belonging together) with members of (commercial, political, social) communities constructed by the newspapers. Described as a macro-phenomenon (structure or culture), discursive landscape also refers to the basic orientations of human beings. It provides spatial linkage between members of a collective (interest or identity).

But in this sense the term regional needs to be defined in new ways. In this analysis, the rethinking of the concept of region is defined as a system of a representation of spatial and social relations (see Allen et al. 1998). Regions then, are constructed and maintained in these relations. Regions are not facts to be found out there as geographical or physical entities. They are processes happening at different scales. These processes have 
different speed in social change and different variety of counter-forces causing regional inertia. And if scale is defined the ratio between the size of something real and that of representation of it - we can describe how the discursive landscape is mapped in the newspapers. This enables us to make distinctive, though not always analytically exclusive borders between the different scales, fundamental to the definition of each type of region.

Different geographic scales construct three levels of identity. Macro scale identity could be European identity, whereas meso scale identity is formed in cultural landscapes having ingredients both from national (i.e., Finnish) identity and regional (i.e., Karelian) identity. Micro scale identity is the individual choice in different situations where people represent themselves upon their priorities and situational constraints (for example, as a consumer, in a professional role, or as a citizen). These scales are analytical frameworks for describing a regional identity construction process. The term meso-scale is particularly problematic, though, because it spans a wide range of intermediate identities between micro and macro. Meso-scale despite of this, in my analysis has real relevance in two senses. Firstly, it is a scale that in some way balances off identities at higher and lower levels. Secondly, it is a scale that approximates the geographic extent to which dominant regional identities may or may not develop.

\section{Discursive Landscape and Economical Constraints}

Regional newspapers certainly maintain and construct these above mentioned identities - but regional newspapers are commercial enterprises as well. How these economical constraints effect the content of the newspapers; what kind is the relation between local journalism and the scales of identities constructed in newspapers?

There is a common academic myth of an impersonal macro economy working either at an ethereal level or a base level. As Bonden $(1994,20)$ pointedly writes, this usually refers to the fact that academics have forgotten that "society does not happen at different levels, research does" The social character of economy, as represented in the discourse of regional newspapers, can be defined more as a diachronic than synchronic category, especially since the many social practices in the end are intertwined with financial constraints. When analysing journalistic 'landscapes' and different features of regional economic structures (fiscal and monetary issues, regional subsidies, state interventions as landowners or state's commercial and trade policy) the close relation between region and state (centre-periphery nexus) and also the economical structure of the region and its newspaper readers has to be reflected.

In traditional analysis of regional media economical factors are usually taken in mainly as structural or institutional variables and treated autonomously without reflecting their impact on content, besides the share of advertising in the annual turnover. This is understandable, because usually the journalistic content of the newspaper and the newspaper as business has been seen as separate phenomena for analysis. This assumption leans on a traditional justification of journalism, where newspapers are seen as serving a democratic function, independently investigating their subject matters in order to provide full information to the public - or even take the citizens along as some public journalism -projects have done- without implicit commercial intentions at first hand.

But if we look at the rather simple example of Finnish regional press from the view of declining revenue sources, these above mentioned constraints can be seen as linked with national, not only regional economy. Earlier, the trend of newspaper economy (measured 
as the common turnover of advertising) has been found to follow the development of the GNP (measured at a national level) with a slight delay. During the recession period this causal link proved to be false. Looked upon from a regional point of view, in some cases the decline of advertising was even more closely linked with the development of regional GNPs, whereas in other cases interesting deviance from this trend could be found.

Table 1. The Decline of Advertisement/Revenue Share and Regional GNP 1989-1993

\begin{tabular}{lcc} 
Province & Decline of advertising (\%) & Decline of GNP (\%) \\
\hline Southern Finland & 39 & 23 \\
Kainuu & 34 & 19 \\
Lapland & 32 & 23 \\
Northern Karelia & 28 & 23 \\
Southern Ostrobothnia & 13 & 26 \\
\hline
\end{tabular}

Source: Löyttyniemi 1997, 120.

During the recession, the state supported export industry. Regions where there existed export firms and enterprises dominated the economy. Due to that, GNP developed more positively within regions where the economical structure favored state support for export. State intervention, however, failed in the attempt to reduce unemployment during the time-span.

Consequently the economy of households remained narrow, affecting both the distribution and revenue sources of the newspapers. For example in Kainuu, dominated by the forest industry, the decline of GNP was relatively smaller than in other regions. The high unemployment rate of the region, however, reduced the turnover of the regional newspaper dramatically. The decline was second fastest in comparison to the other regional newspapers studied.

At a macro level, the Finnish press was affected by the recession, which could be seen in a fall in circulation and coverage as well as in the overall share of newspapers in media business. Several newspapers closed down altogether and the total circulation began to decline for the first time since World War II. Between 1990 and 1996 the total circulation dropped by 17 per cent.

There are some simple sociological explanations for the decline in circulation, like the economically narrowing conditions of the households due to the unemployment. But the strategies of the newspapers were at least as important. Calculating their trade-off within their circulation area, many papers soon figured out the geographical space that was optimal to cover. That led to a trend of 'turning inward', at least concerning the regional material and local news agenda. The agenda covered spatially narrower territory, but more than ever the newspaper was married with the economy of its area.

It is true, that the finding that newspapers are consumer products by no means is a novelty. In general it might be said that journalism also in a Finnish context has aimed at the reader as a consumer as much as a voter or a citizen. ${ }^{7}$ The decline in newspaper circulation, however, seems to have triggered off a development that increased market economy values in newspaper publishing. Apparently, this trend is more or less similar in other Western countries (Leather 1998). If culturally the most powerful or preferable values of the culture can be read from the newspapers, this may only be because journal- 
Table 2. Circulation of the Newspapers 1988-1997

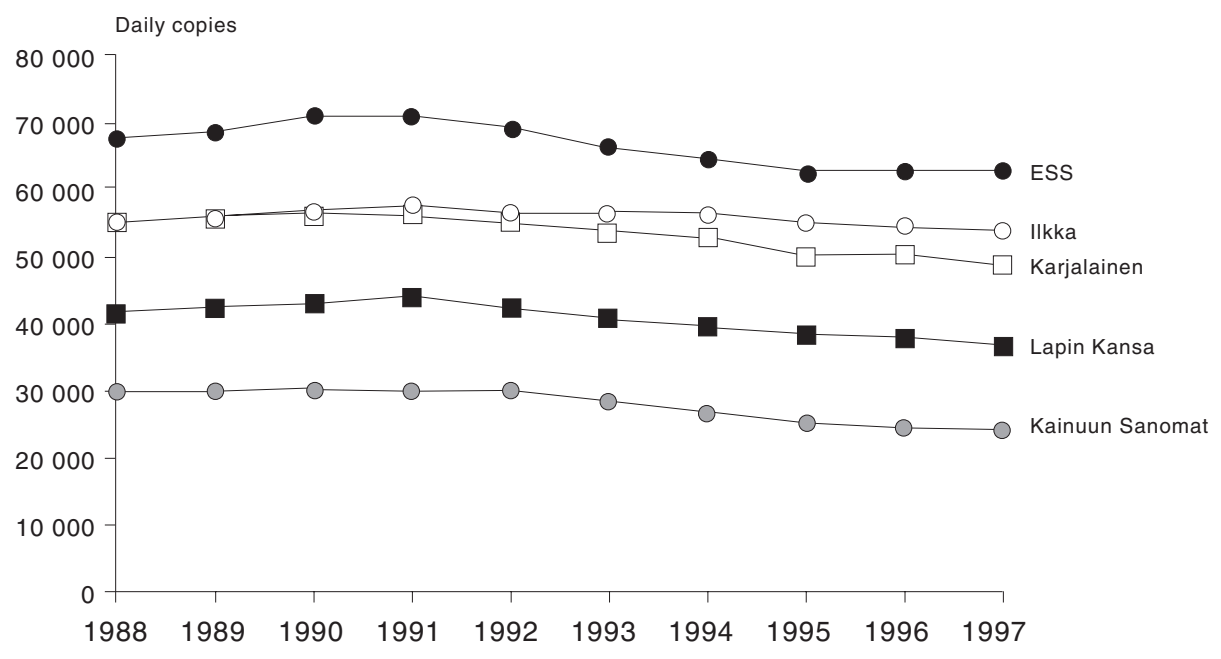

ists tend to gang up with political, commercial and cultural elite (Mancini 1992; Jacubowiz 1991.) Newspapers are textual sites, constructed landscapes that displayed the most ideologically preferable categories of common sense - in this case economical categories.

Newspapers as textual sites, however, reflect many types of communities of the geographical regions: not only economical, but political and cultural as well. Newspapers as commercial enterprises also create their own communities as employers of the journalists and other staff of the media industry: producing, printing and distributing the newspapers daily. The newspapers also create a discursive system, or formation, as a background for discursive landscapes, as defined above. Discursive formation is neither defined by a particular object, nor by style. It is thematic, a play of permanent concepts or persistence of a theme, but it must be grasped in the form of a system of regular dispersion of statements (Foucault 1980, 63). There is not, of course, only one system at a time. We should therefore talk of systems. In this analysis, journalism is seen as a system or a discursive formation capable of dispersion of statements.

These discursive systems are constructed with the help of a professional codex and ideology of everyday practice (Thrift 1996, 176). These practices as ideologies differ partly also regionally, i.e., they are connected to the social space(s) and place(s). When we analyze these textually and historically changing cultural practices, we are dealing with processes operating at different spatio-temporal scales. And it is clear that there is a social reality to each of these levels. The social reality of each region is constructed in the matrix of scales and historically contained images of identity of the region. These constructions can include different sets of relations (centre-periphery; urban - rural; agriculture-industry; historical and symbolical event - future visions and predictions).

\section{Discursive Landscapes of the Region}

In the following part, the theoretical ideas presented above are discussed in the context of the region of Northern Karelia and its newspaper Karjalainen. The nature of this part 
is more descriptive than analytical. More detailed statistical analysis is left out in this article. On the basis of a descriptive account of the lines of discussion in the editorials, I will propose some answers to the questions I have formulated earlier; how are different geographical scales used in the editorials of Karjalainen when constructing 'us'?

Northern Karelia is in focus because of its blend of distinctive cultural features on one hand, and the heavy transformations the region has faced during the last ten years on the other. It has remained a culturally original borderland between east and west. It has a common history with the Lake Ladoga region that after WWII became Russian territory, and has throughout history constructed a 'borderland' identity. Northern Karelia is the eastern part of Western Europe - and the economic setbacks of the crisis effected the region profoundly turning it to one of the poorest regions in Finland. Northern Karelia can be seen also as a reflexive space for societal transformations - at macro-, meso- and micro- scales. These transformations (EU-membership, the break down of the Soviet Union, the question of rights to the former Finnish parts of Eastern Karelia, heavy migration to Southern Finland) were displayed in detail during the last ten years on the pages of Karjalainen.

During the time studied, Northern Karelia formed a distinct functional unit in an administrative sense, but it presents disparate pictures culturally. This was reflected in the regional newspaper that displayed both elements inherited from the area of old Karelia on the Russian side of the border and elements typical to the East of Finland. The strong emphasis on agriculture and forest industry are playing crucial parts both politically and as an element of self-understanding of the region (Paasi 1986).

Table 3. Variation in Themes and Number of Editorials in the Newspapers Studied 1988-1997

\begin{tabular}{|c|c|c|c|c|}
\hline Themes $(\mathrm{N})$ & $\begin{array}{l}\text { uthern Finland, } \\
\text { Lahti region, } \\
\text { ESS }(\mathrm{N}=118)\end{array}$ & $\begin{array}{c}\text { Southern } \\
\text { Ostrobothnia } \\
\text { Ilkka }(\mathrm{N}=147)\end{array}$ & $\begin{array}{l}\text { Lapland } \\
\text { Lapin Kansa } \\
(\mathrm{N}=230)\end{array}$ & $\begin{array}{c}\text { Northern Karelia } \\
\text { Karelia } \\
(\mathrm{N}=474) \\
\end{array}$ \\
\hline $\begin{array}{l}\text { Regional industry } \\
\text { and commerce }\end{array}$ & 25 & 14 & 51 & 123 \\
\hline $\begin{array}{l}\text { Agriculture and } \\
\text { forest industry }\end{array}$ & 4 & 13 & 35 & 60 \\
\hline $\begin{array}{l}\text { Development of the } \\
\text { region and comparisons } \\
\text { at national level }\end{array}$ & 33 & 23 & 37 & 109 \\
\hline Regional subsidies & 2 & 1 & 2 & 10 \\
\hline $\begin{array}{l}\text { Europe and the } \\
\text { regions nearby }\end{array}$ & 4 & 16 & 20 & 18 \\
\hline $\begin{array}{l}\text { Statements in } \\
\text { regional politics }\end{array}$ & 29 & 57 & 59 & 58 \\
\hline Regional identity & 0 & 4 & 21 & 16 \\
\hline Center-periphery axis & 9 & 17 & 61 & 58 \\
\hline $\begin{array}{l}\text { Depression and } \\
\text { dismantling welfare state }\end{array}$ & 12 & 2 & 5 & 22 \\
\hline
\end{tabular}

The focus of the editorials 1988-1997 of local and regional issues highlights some features of this above mentioned fragmented cultural landscape. Editorials can be analyzed in order to interpret the development of textual landscapes through time and the diffu- 
sion of culture - the spread of ideas, techniques and practice. Editorials can also be analyzed periodically in a longitudinal setting that enables 'sociological gaze' to spot formative disjunctures and ruptures in the transformation of the 'politicality of space'

In light of the quantitative content analysis, Karjalainen has the strongest provincial spirit, at least if we make this interpretation on the basis of the amount of editorials addressing the local and regional issues. In the editorials, the surrounding region is fairly consistently presented as a province. And the internal images of the region are stemming already from the historical rise of provincial activities. The regional economical structure comes through clearly as well. Agriculture and forest industry, regional development and centre-periphery -nexus define the main poles of this discursive landscape.

\section{Temporal Transformation of Karelian Identity Who Are We? What Is Going On?}

The different newspapers do not have the same interpretation of the 'crisis'. Also the economical depression itself entered some discursive landscapes earlier than other, and it also left those landscapes later. The newspaper Karjalainen lived in a state of 'textual recession' a relatively short period. The discourse on the recession had two temporal parts in the editorials; first one from 1988-1993 (the darkening years) and the second 19941997 (slowly evolving economical growth). The overall atmosphere was not totally pessimistic (or aggressive towards rule or policy implementing institutions or actors, i.e. the government, the president, the party elite etc.) either. As a region, perceived to have a strong provincial spirit, in the editorials this spirit was in the first years of the crisis extremely weak historically or culturally but stronger in clearly administrative and policy questions.

One explanation to this could be that strong historical provincial spirit often was expressed in combination with old stereotypes of 'karelianism'. A more realistic explanation could be that the economical conditions never fully enjoyed the 'boost' in this region. The so called casino economy that was seen in other parts and especially in Southern Finland never reached Northern Karelia.

\section{Where Is the Boost? The Years 1988-1990}

The recession, or the first signs of it, were seen in Karjalainen during the summer of $1988 .^{8}$

Discussion revolved around the declining population (migration to Southern Finland) and the failing generations shift in the farms. ${ }^{9}$ Although the Helsinki area still enjoyed wide and flourishing expansion, the peripheral regions and provinces had entered a time of threatening economical visions. North, East, West and South were living their own social realities. The difference between Karelia and other areas was basically seen as a threat against the Northern Karelian way of life: agriculture in villages, a lively cultural landscape and the maintenance of 'Man and Nature', i.e., the balance of an agricultural way of life and a rustic peasantry. Agriculture in rural areas and the farmer population in Northern Karelia has enjoyed support from the state and have been valued culturally and historically, maintaining the core assets of Finnishness in spite of its peripheral geographical position.

The societal transformation that began 1988 turned values (the importance of population and unfunctioning infrastructure all over the country) from geographical democracy to the right of the (economically) fittest (the Helsinki area). During the 'boost' era of the 
late 80 s different values, like urbanization, westernisation, yuppification and commodification were highly valued. Rural or peripheral romanticism did not arouse the feelings of sympathy that it did some years later, in during the mid-90s.

In 1989 the theme of the East border question was activated in Karjalainen. When the Soviet Union collapsed the geopolitical situation changed, effecting the border areas of Finland as well. The bigger change, however, was the growth of the new mentality that this transformed power-balance nourished. The end of Finlandisation triggered off many topics of discussion that had been banned earlier. The Karelia question was one of them. That kind of new openness in discussing the eastern border had not been possible in Finnish newspapers before.

The sentiments in Northern Karelia were largely patriotic. Incidents, speaking of xenophobic sentiments in the region were widely discussed. Karjalainen was balancing the regional insecurity by creating visions of Great Karelia, e.g. connecting geographically ceded areas (The Soviet Republic of Karelia) back to the Finnish nation-state. The discussion faded as the economical consequences of an incorporation with Finland of the poor Russian Karelia and its mainly Russian speaking population became clear. The interest faded even more as the economic situation also on the Finnish side grew worse.

For the first time in Finnish post war history let the public discourse open for statements concerning the eastern border. Karjalainen was nourishing the spirit of Winter War and keeping up the discussion concerning the ceded areas. At a national level, the political elite tried to downplay the discussion and it hardly at all expanded to other media. In those few cases that this happened, arguments of the economically catastrophical state of the Republic of Karelia (non-existing infrastructure or services) were put front referring to 'Realpolitik'.

Karjalainen's attitude towards the State was not hostile, however. Here it differed from some other regional newspapers. ${ }^{10}$ The social reality of Northern Karelia was linked more to the changed situation in the Soviet Union than was the case in other regions. In other newspapers the upheavals of the Soviet Union were documented as foreign news, not as domestic issues.

In Karjalainen, EU was not an issue at all in 1990 whereas, for example, other dailies in Finland entered already in EU -era. ${ }^{11}$ Karjalainen still, was scaling the Northern Karelia region as a rural area inside the nation. This area was assessed in relation to other areas in Finland. The area was fading when economical expansion and employment could not be secured for the people. Agricultural production and forest industry were seen generally as backwardness and low-productive enterprises compared to hi-tech, tourism and the service -sector. The politicality of space of Northern Karelia was evident - the economic recession were interpreted with the help of changing geopolitical situation.

\section{Recession Inhabits the Mentality. The Years 1991-1993}

In Karjalainen, 1991 was the turning point where the regional newspaper began to reassess the development and planning concerning the area. A feeling of disparity and undemocratic regional policy could be read from the editorials. ${ }^{12}$ An interesting transformation was the change from purely economical crisis to mental 'crisis'. ${ }^{13}$

This meant a mental turning point. The emphasis was laid on hope, visions, planning, re-evaluation of the situation mixed with concrete concern of the financial problems communities and municipalities faced due to the scanty trade and declining subsidies. An interesting detail during the year 1991, was that the scale of looking at things 
got smaller in the newspaper Karjalainen. The urge to keep up the spirit was a crucial part of the mentality in Karjalainen. This spirit was largely coupled with rural and countryside 'free peasant' connotations. At a regional level the double link to addressees was easily read. Editorials were addressed to the subscribes, e.g. to the geographically limited main distribution area - but as well to the political elite situated in the country's capital, Helsinki.

Economically, the year was a hard setback to the nation. Budget cuts concerning regional infrastructure, diminishing regional subsidies, a darkening horizon in regional business - all those were variables that helped this journalistic 'turning inward' process. Even the overall share of local materials and news items decreased (also Moring 1999). The biggest concern was the economy of the municipalities (communes) and the developmental backlash the recession had created to the rural development.

The national economy was purely financially entering an era where the earlier regional policy had become too costly and unaffordable to the state. That was seen also in other regions. Regional or provincial values were not in fashion as such - sympathisers were rare, although the Centre Party with its agrarian roots was in power. The Centre Party dominated national politics faced severe difficulties that certainly did not help to keep up the empathy towards expansive regionalism. Karjalainen was - textually and metaphorically - treating the recession as a disease or a natural catastrophe that could be 'cured' if just right 'cures' could be found within the region. The economic crises and the region were mixed when symbolic meaning and interpretations of the economic crisis intertwined in a way that juxtaposed economical events with overall mentality. The region turned inwards in terms of regional comparisons.

Statistically speaking, year 1992 was the darkest period in the national economy. The regions tried to manage with narrowing subsidies as well as with less sympathy towards the agriculture. Partly also the regional discussions revolved around bigger questions and depression was for the first time seen also as 'national' crisis, not only economical. Discussions on how to administrate regions was one of the topics. This may seem paradoxical, but it was linked with economy of the state. The regional system of governing administrative provinces changed, partly because the older one was seen as too ineffective.

During 1992 Finland was preparing its application for an EU -membership, as well. The discussion of the transformation to a 'Europeanised' nation was raised in all regional as well as national newspapers. This discussion got different co-ordinates in different Finnish regions whereas the national daily, Helsingin Sanomat flagged in favor of the membership almost without journalistic criticism (see Mörä 1999). In Karjalainen, EU was seen as giving hope to transform the political space between east and west, and once again the border question was activated. ${ }^{14}$

A difference, when comparing to the other regions, was that for Karjalainen EU, depression and the Karelia question were linked. Moving to the west gave new justification to statements in this direction after a long period of Finlandisation. The East and West within Finland also reflected the threats and possibilities of EU differently. Karjalainen in the East was strongly in favour, linking older foreign political questions to the EU option. In 1992 Karjalainen leaned on a national scale once again - but from the patriotic vantage- point. To these nationalistic statements were mixed hopes, visions and fears concerning the European Union.

In 1993 there was a little rise in the national economy. The discussion of the EU membership gave boost to lightening visions. Northern Karelia and Karjalainen were 
filled with developmental strategic openings in various areas. Dismantling the welfare state had had its consequences that were easily seen in the area. Closing down schools, post offices and stores in the villages caused images of the rural areas being deserted. Karjalainen was returning from the national scale to the regional scale, bringing problems of periphery into the discussion. ${ }^{15} \mathrm{EU}$ was still seen positively, in terms of Europeanisation, strengthening western connections.

A distinct feature in Karjalainen was the turn inwards - cures and tools were sought inside or within the area. During the year 1993 the fact that the support from the state will not keep the economy of the municipalities in balance became quite clear. Also the establishing of new administrative provinces and the planning for cutting expenses in administration of (historical) provinces created insecurity. The historical provinces had deeper roots in the Finnish mentality than the national bureaucracy (i.e., the government) understood. In most newspapers questions of administration were among the top issues.

\section{Karelia Goes Europe. The Years 1994-1997}

1994 was the year of presidential election in Finland. The new president, Martti Ahtisaari, was considered to be free of the burdens of more politically involved candidates. Though the Centre Party generally had an advantage in the periphery, in Karelia the social democrat Ahtisaari collected a relatively good support. The scale of national got even more ingredients from the EU -membership discussion. The regions were reflecting themselves as part of the state, but also as part of the larger geographical community with their own specific needs and strengths.

In Karjalainen, the new European scale gave hope to regional discussion - it was seen as facilitating a stronger economy for the national economy but also as a supra-national tool to maintain the balance between urban centres and rural areas ${ }^{16}$. Compared to other dailies, Karjalainen saw European Union as an option, not as dystopia. ${ }^{17}$ The European scale fitted the strong patriotic and provincial spirit, giving new credibility to the old vision of a border land linking western countries and the East. Finland was more than ever part of the West. The state had earlier patronised Northern Karelia and due to that the regional support in 'Europe of the Regions' was highly welcomed. EU was seen also purely in economical terms - giving perhaps more support to this specific area.

After a referendum in the autumn 1994, Finland became a member of EU in 1995. After that, the regional discursive landscape tuned into interpretations of the future within the larger scale dominated by the European Union. Northern Karelia was part of the nation but more than that, a region that could get backup from other regions in Europe. More than a national question, the question of the life in rural areas was framed in the dichotomy between the core areas of political elite and decision-makers, and peasant people in peripheries rural areas. In Karjalainen, the opposition against budget cuts rose as well. The nation as an organic super-metaphor was now economical, not cultural in its nature. ${ }^{18}$ The editorials in Karjalainen were framing problems more as 'Finnish' and 'national' scale - and regional issues as developmental questions. Paradoxically, in Karjalainen it strengthened the expressions of patriotic nationalism.

The relation between the region and the state (in regional policy and centre-periphery issues) activated in Karjalainen and the state was seen in a negative light. Financial support to the areas that were dominated by export companies and firms was stronger than to Northern Karelia that was dominated by the forest industry and farming. Forests, that had been historically the backbone of Finnish trade were losing importance and facing the transformation the new technology (for example Nokia) caused to the 
economical structure of Finland. New technology was becoming the flagship of Finnish industry and manufacturing instead of pulp, cellulose and paper.

During the year 1996 the national economy recovered. Expenses in administration in municipalities and welfare state services had, however, been cut and the fact that there was no way back to the golden years before recession was quite clear. Uneven regional economical structure had, anyway, created the feeling of regional disparity that national policy would not take into an account. Discontent addressed to decision-makers was aired in Karjalainen and stronger political opposition could be seen. ${ }^{19}$

Karjalainen was strongly questioning the value-basis of the nation-state after the recession. Rusticity had publicly gained more sympathy and traditional and historical values were more in fashion than before. Rusticity was seen also for the first time at a European scale. That strengthened the regional self-esteem and also loosened the stigmatized image of rural backwardness of the Finnish countryside. Finnish film industry, for example, was using the countryside and rural life for the first time after the 50s as material for domestic production. The romantic rediscovery of folk culture, which again was mobilized in the interest of creation of national identity and nationalism in Finland was, however, hardly seen in the regional newspapers. The regional newspapers, especially Karjalainen, were again constructing and framing the geographical area politically more than culturally. This meant that regional identity was intertwined with the questions of provincial administration and European Union more than with the people or the preservation of 'regional culture'. Popular culture, however, used recovering nostalgy and folk culture in TV-serials and films.

Economically, the sun was rising during the year 1997. GNP showed fast growing numbers of the import and employment. Declined areas of industry (trade of wood products) were also recovering. During the last year of the time-span studied Karjalainen voiced a new kind of sense of (regional) autonomy in Northern Karelia. Issues in the editorials were framed from inside (within the region) as well as from outside (looking at the area in a broader perspective) ${ }^{20}$

In other dailies, the tone towards the state was often quite harsh, whereas in Karjalainen the approach was co-operative, understanding, framing things both nationally and regionally, but not in adversarial terms. The framework was not exclusive but inclusive. Karjalainen was taking positions in region-nation; region-Europe and region-region questions. The patronizing power of the state was not felt so strong anymore. Also future visions were quite positive.

The territorial and symbolical (conceptual) vision transformed clearly from a historybound agricultural region to a more active actor in national politics. The scale of constructing regional identity changed but this transformation did, however, not go through a hostile period between the state and the region.

\section{Karelia - the Nearest Siberia of Brussels?}

So what happened in Karelia? As a region Northern Karelia went through the economic recession for sure. But was it economical, political or cultural transformation from the journalistic point of view? Was the economical change, for example, a disembedded sphere in Giddensian terms? Or did the economy or money get sociological, cultural and political meanings?

The newspaper Karjalainen created its own political space during the time-span researched. The official regional policy in the editorials of Karjalainen was in favor of rural and agricultural ways of life. The territorial image has altered over time from focus- 
ing on national periphery towards emphasizing Northern Karelia's character as a European scale region. Economical change was linked to the foreign policy and regional identity. Discursive landscape of Karjalainen had very strong inertia in terms of activating historical interpretations of 'what is really going on and where are 'we' heading? Compared to the mainstream nation wide publicity, the regional media socially as well as culturally reflected economical issues from the local vantage -point, of course. As an opposite in Giddensian terms, the news of regional economy was not a disembedded sphere but a very embedded practice of everyday life of the region. It is in this perspective 'crisis' in national economy can be considered an overall social fact - but as a social fact it differed from region to region. The implication of this development is not simply a descriptive or empirical matter, but necessarily implicates theoretical problems, as well.

The dynamics of local-national-global interests and identities and their problematic constructions of the local 'we', regional 'us' and national Finns in the closer analysis cannot be seen as distinct constructions, but are rather intertwined in spatio-temporal processes with epistemes and regimes that are distinct to the area studied. The imagined public within given distribution areas and the addressees of editorials did not always overlap. In this case, however, the changing ecology of the editorials responding to wider socio-cultural shifts was quite fast. The editorials of Karjalainen were perhaps political backwaters of the national discussion - but more than that, they were a reflexive space for transformation and diffusion that took place in the specific discursive landscape. The center of value and meaning production emancipated from the local constraints ('localizing' processes) that was political and ideological, but not aggressive or hostile.

To incorporate other spatial dimensions, not only 'regional' or 'local' into the analysis changes a lot in the evaluation of the landscape and the local culture. People are not banks of cultural memories, although analyzing newspapers as cultural documents could lead us to assume so. As a consequence of that, the analysis of cultural practices may replace the one of cultures in the future. Also 'identity practices' may replace the defining of national or regional identities. But these practices, however skillfully defining the stories stemming from cultural studies, will and still have spatial constraints.

Although I'm claiming that economical structures have impact upon the spatial 'lifeworlds' I am not seeing places only or solely as palimpsests of capital. Regional analysis should not imply base - super structure models, though historical materialism continues to shape 'discursive landscapes'. In my analysis, also the cultural field within which the concept of 'cultural' identity has operated, has become more than just a spatial metaphor. Regional cultures are literally embedded in the web of signification of 'politicality of space' that is bound to territorial identity structures. I am not claiming that these constructed regional identities as discursive landscapes have ontological essence as such but I do claim that these discursive landscapes do differ. And even more, they are textual and historical containers. They are socio-spatial codes used implicitly to ideological purposes when giving hermeneutical devices for the habitat.

As Friese and Wagner $(1999,144)$ pointed out, the relation between political and intellectual positions is never stable. Thirty years ago the term structure had a rather critical and emancipatory flavor and 'culture' a conservative one. Now this relation has almost been reversed. Current studies of cultural cartographies foreground the state of affairs, that then very concepts of homogenous national cultures, are in a profound state of redefinition (Bhabha 1994, 5) It strengthens the argument of Appadurai in the sense that 
cultures are not holistic ways of life - but instead are composed by 'people assembling and reassembling fragments from around them' - the different scapes around them. (in Crang 1998, 175.) There is always different scales, as well, in use for understanding what is going on - around us.

Northern Karelia perhaps is not the most interesting spot in the world - most of the readers don't probably even know where it is. But as an example of the specific timespace it raises bigger questions on identity practices; If interpretations of economical situation can vary within one nation-state as much as described - how common issues concerning for example an larger scale are addressed differently when comparing nations? Is it possible to gain mutual understanding if we're living on different discursive cartographies? What is the most dominant story of geopolitics or history we face in the next millennium? When just starting counting Finlands - I find myself wondering how many Europes there might be?

\section{Notes}

1. The concept of discursive landscape originates in human geography and the work of the Finnish geographer Jouni Häkli (1998) although he has used the concept referring to the national ideoscape (Appadurai 1996) as historical container.

2. In 1997 the Board of the Academy of Finland launched a multidisciplinary, problem-oriented, and applied research programme, 'The economic crisis of the 1990: reasons, events and consequences' dealing with the socio-economic crisis. The Academy channelled FIM 25 million (equivalent to 4.2 million ecus) to the programme. It is the largest research programme ever in social sciences in Finland.

The programme contains a research project of media, 'Media coverage versus citizens experiences in the crisis'. The aim of this project is to analyse the public discussion on the economic crises and the experiences of different population groups. The object of the project is to find out what kind of challenges the economic crisis created to democratic system, to the ability to political elite to discuss in an understandable way, to the ability to the media to reflect different views, and to the capability of ordinary citizens to participate and influence discussions concerning themselves. This article has been written as part of this research project.

3. The quantitative coded material consisted of four regional newspaper's local news, editorials, columns and letters-to-the-editor. Within the research period 1988-1997 every second newspaper was coded. In the code schema 'local' material was defined as articles reporting issues concerning the distribution area of the newspaper. National and international news were excluded but only if they did not have any link to localities within the region, i.e a local perspective. Totally the body of coded material consists of 36,093 observations. The number of observations divided between newspapers is: Etelä-Suomen Sanomat 6,927, Lapin Kansa 8,324, Ilkka 8,860, Karjalainen 11,982. The code schema was constructed of nine variables (year, month, date, newspaper, genre, temporal form of the headline, theme, development (scale-positive, neutral, negative) presented in article, headline in written form. The number of themes were almost 90 (the most descriptive themes reported below). In addition, qualitative material (articles, editorials etc.) were collected from the newspapers. The amount of articles for qualitative study is qround 500. A detailed analysis of this material was not available at the time this article was finalized.

4. Structural and political implications, however, can not be left totally unstudied either. Recent research concerning unemployment rates and their regional implications (Böckermann 1998, Peltola 1997) in Finland show that geographical areas differ more strongly after the recession than before. The present and continuing growth of national economy will probably increase these regional differences with an accelerating speed.

5. Palimpsest is a term originally deriving from medieval writing. It meant a writing tablet that could be reused many times and every time for a new set of material. However, the tablet could never be rubbed totally clean. Over time, layers of prior scripts would build up over which the current one was written. The term has been taken as a metaphor for landscape change, where current uses do not completely erase the marks of the history. (Crang 1998, 192)

6. In his book 'The Diary of an Opportunist' the Finnish poet Paavo Haavikko polemically claims that the Eastern Finns were conquered by the Western Finns. The method of this cultural pilgrimage was astute, and based on the method of cultural standardization by symbolic elements like literature, myths, tales, 
etc. The Finnish nation was united by establishing internal differences. The regional landscape formation was grounded on the myth of a Finnish identity and its subcategories. The most important contribution for nation building was the work of Z. Topelius's, Maamme kirja (The Book of Our Land) published in 1875. The strength of the cultural power of the book was partly due to the need to create and unite state and nation also in a literary style. At the same time, the book described the land and landscape in such a way that the people could identify with it easily, but also displayed regional differences praising different folkloristic codes inventing the regions culturally - as a part of a whole nation. (Häkli 1998)

7. The nature of the symbiotic reality of the local and regional journalists and members of the local business community is also easily explained. Industry sources provide revenue for the action via advertisements, sometimes even content to the section via press releases and legitimacy through quotes. Market -oriented journalism is one layer of the ideological practice of everyday journalistic work although not the whole picture. When looking at the national daily, Helsingin Sanomat - or almost any other big European daily - their tone is backing the supplements of travel, computers, personal finance, car and motoring sections. The transformation of newspapers to increasing market-orientation or commodification is becoming even clearer. News-value has a different meaning and is more or less defined by the business-friendliness. Stories can rather be judged in terms of their 'audience-friendliness and advertiser attractiveness' than in terms of the information value aimed at the informed citizen. (Leather 1998, 251) The scale and the region of textual production are defined with the help of consumer's society.

8. 'The declining (agricultural) productivity effects employment' (15.7.1988.) 'Agricultural production has to be prepared for difficult years' (18.11.1988). Next summer the editorial statement suggested an other type of solution to narrowed regional conditions, 'Big publicity as a (regional) resource' (4.7.1989).

9. The discussion of migration had clear historical roots. One part of the state's military policy had been to keep border areas populated on the Finnish side, whereas the Soviet Union had treated Karelia as a military buffer area and because of that the area had been kept largely unpopulated. The emigration from Northern Karelia was compared to the transformation of the 70's, when approximately 400,000 people were emigrating to Sweden in search for jobs.

10. ESS: 'The state is eating from your table', (30.10.1989); Ilkka: The development program within the province of Vaasa should be started immediately (19.3.1989).

11. Ilkka entered the EU -era: 'Agriculture can't be sacrificed to the integration (4.2.1990)' Does Finland need own agricultural production or food manufacturing? (16.6.1990) 'Budget increases pressure even more in poor municipalities' (26.8.1990) 'Farmers are afraid' (15.11.1990).

12. 'The amount of the development share of the province should be re-evaluated' (8.4. 1991),' The dimensions of the development strategy of the province' (3.6.1991), 'Communities in deep debts, where do we get help? (3.6.1991).

13. 'The belief in entrepreneurship can be let broken' (15.7.1991). In some cases the tone was even more pessimistic:' Empty hopes should not be nourished' (31.8.1991). But by the end of the year, a more hopeful tune won terrain: 'Dismantling the welfare state: No specific reason to Doomsday visions' (12.9.1991).'There are natural cures for the recession' (26.10.1991);'Towards the life after recession' (26.10.1991); 'More boost to regional politics' (15.11.1991).

14. 'Transformation of Europe supports the discussion of the Karelia question' (7.2.1992),' 'Talking about Karelia (the border dispute) reflects new openness' (4.7.1992), "The question of Karelia should not be buried terminally' (14.7.1992) and “The value of national sovereignty gains importance in times of upheavals' (5.12.1992).

15. 'The recession of tourism should be cured by marketing' (9.2.1993), 'Northern Karelia now needs longterm strategy' (26.6.1993),' Closing the schools have various effects' (15.8.1993),' Provincial cure for the depression should be sought from the private forests' (15.8.1993), 'Co-operation (in regional development) gives us power' (2.3.1993).

16. 'The options of EU-membership should be benefited in Northern Karelia' (3.3.1994), 'Spring lights in the Northern Karelia' (3.3.1994),' Finland is entering the new period of growth' (16.4.1994), 'The signs of springing growth should be nourished in Northern Karelia' (1.5.1994), 'Border regions have difficulties to find empathy in budget negotiations' (7.9.1994), 'Regional differences will diminish only with production and export' (20.10.1994), 'The public discussion should be guided to the contemplation of the Finnish policy in European Union' (5.1.1994).

17. The difference between, for example, Ilkka and Karjalainen, though both of them are to a great extent provincial - is in the scale of looking at things. Southern Ostrobothnia has not been a geopolitically sensitive territory. Thus, EU was seen only as the end of the agriculture that could not produce enough 
effectively. Northern Karelia was ready to mentally open a door to Europe, and the autonomous position of the Karelian farmer was never put into question.

18. 'Rural areas are fading if decision-makers do not get acquainted with the research results' (13.1.1995);' The economy of municipalities is getting better, tolerance for the cuts not' (2.3.1995); Northern Karelia has to build a positive atmosphere to the development' (13.12.1995); 'Precise account keeping is the savior also for the Finnish agriculture' (21.12.1995).

19. 'A representatives of Northern Karelia to EU and to the Republic of Karelia' (4.1.1996), 'The balanced development of the nation-state requires new thinking from the decision-makers' (13.1.1996),'Power from central agencies of rule implementation to regional and local levels' (8.2.1996' The regional subsidies to wealthy areas should be stopped' (14.8.1996),' Rural projects should be launched nationally' (3.5.1996), 'The development of Eastern Finland will not advance with back-and-forth strategy' (15.5.1996).

20. 'The welfare of the country is not solely a transfer of income' (8.3.1997), 'Northern Karelia rises only with the help of positive activity' (11.7.1997), 'The State does not longer administrate Northern Karelia' (1.9.1997), 'Saving operations solves the heritage of the welfare state' (9.19.1997), 'The rise of the national economy should be trusted also in Northern Karelia' (7.11.1997).

\section{References}

Anderson, B. (1983) Imagined Communities. Reflections on the Origin and Spread of Nationalism. London: Verso.

Alexander, J. et al. (eds.) (1986) The Micro-Macro Link. University of California Press: California.

Allen, J., Massey, D. \& Cochrane, A. (eds.) (1998) Rethinking the Region. London: Routledge.

Appadurai, A. (1996) Modernity at Large. Cultural Dimension and Globalization. Minneapolis: University of Minnesota Press.

Bauman, Z. (1998) Globalization. The Human Consequences. UK: Polity Press.

Bhabha, H. (1994) Nation and Narration. Routledge: London.

Bird, J., Curtis, B., Putnam, T., Robertson, G. \& Tickner, L. (eds.) (1993) Mapping the Futures: Local Cultures, Global Change. London: Routledge.

Boden, D. (1994) Business Talk. Cambridge: Polity Press.

Böckerman, P. (1998) Alueet työttömyyden kurimuksessa. Kunnallisalan kehittämissäätiö. Vammala.

Crang, M. (1998) Cultural Geography. London: Routledge.

Ekecrantz, J. \& Olsson, T. (1994) Det redigerade samhället: om journalistikens, beskrivningsmaktens och det informerade förnuftets historia. Stockholm: Carlssons Bokförlag.

Foucault, M. (1980) Questions of Geograhy. In Power/Knowledge. Selected Interviews and Other Writings 1972-1977. Oxford: The Harvester Press.

Friese, H. \& Wagner, P. (1999) Not all that is Solid Melts into the Air: Modernity and Contingency, In Featherstone, M. \& Lash, S. (eds.) Spaces of Culture. City, Nation, World. London: Sage, pp. 101-116.

Gellner, E. (1997) Nationalism. London: Orion Books Ltd.

Gregory, D. (1986) Spatial Structure. In R. J. Johnston et al. (eds.) The Dictionary of Human Geography. Oxford: Blackwell.

Gregory, D. (1994) Geographical Imaginations. Cambridge: Blackwell Publishers.

Haarni et al. (eds.) (1997) Tila, paikka, maisema. Tampere: Vastapaino.

Harvey, D. (1989) The Condition of Postmodernity. Oxford: Blackwell.

Hobsbawn, E. (1992) Nations and Nationalism Since 1780. Cambridge: Cambridge University Press

Häkli, J. (1998) Cultures of Demarcation: Territory and National Identity in Finland. In Herb, G. \& Kaplan, D. (eds.) Nested Identities: Identity, Territory, and Scale. Lanham, LD: Rowman and Littlefield Publishers.

Jacubowicz, K. (1991) The Musical Chairs Policy. In Dahlgren, P. \& Sparks, C. (eds.) Communication and Citizenship. Journalism and the Public Sphere in the New Media Age. London: Routledge.

Jameson, F. (1992) The Geopolitical Aesthetic. Cinema and Space in the World System. Bloomington and Indianapolis: Indiana University Press.

Jarvis, B. (1998) Postmodern Cartographies. The Geographical Imagination in Contemporary American Culture. London: Pluto Press.

Joenniemi, P. (1998) A Europeanized Finland: A Herderian Nation or Hegelian State? Paper presented at Crossroads in Cultural Studies, 1998. Tampere, Finland.

Klinge, M. (1984) Östersjövälden: ett illustrerat historiskt utkast. Helsinki: Söderström. 
Leather, A. (1998) Economic News in Local Mewspapers. In Franklin, B. \& D. Murphy (eds.) Making the Local News. Local Journalism in Context. Routledge: London, pp. 241-252.

Lefebvre, H. (1991) The Production of Space. Oxford: Blackwell Publishers.

Linz, J. \& de Miguel, A. (1966) With-in Nation Differences and Comparisons. The Eight Spains. In Merrit, R. \& Rokkan, S. (eds.) Comparing Nations. The Use of Quantitative Data in Cross National Research. USA: Yale University Press.

Löyttyniemi, V. (1997) 1990-luvun talouslaman vaikutus Suomen sanomalehdistöön. Teoksessa. Hietala, M. \& Oikarinen, J. \& Virtala H. (eds.) Arvot, analyysi, tulkinta. Helsinki: Hakapaino.

Mancini, P. (1993) Between Trust and Suspicion. How Political Journalists Solve The Dilemmma. European Journal of Communication, vol 8.

Meyrowitz, J. (1985) No Sense of Place: The Impact of Electronic Media on Social Behavior. New York: Oxford University Press.

Morley, D. \& Robins, K. (1995) Spaces of Identity. Global Media, Electronic Landscapes and Cultural Boundaries. London: Routledge.

Moring, I. (1999) Alueellinen ääni ja lamajulkisuuden kehitys. Teoksessa Moring, I. et al. Mediakriisi. Lehdistö, lama ja talouspuhe. Helsingin yliopisto, Viestinnän laitos. Sarja 2A/1/1999. Helsinki: Yliopistopaino.

Mörä, T. (1999) EU-journalismin anatomia. Viestinnän laitos. Sarja iA/2/1999. Helsingin yliopisto.

Paasi, A. (1986) Neljä maakuntaa. Maantieteellinen tutkimus aluetietoisuuden kehittymisestä. Joensuun yliopiston yhteiskuntatieteellisiä julkaisuja, No. 8. Joensuun yliopisto.

Paasi. A. (1991) Yhteiskuntatutkimuksen kielestä ja metodologisista implikaatioista: Teoriaa ja empiirisiä esimerkkejä. Terra 103: 3 .

Peltola, O. (1997) Talous kasvaa lisääntyvätkö työpaikat? Aluetaloudellinen näkökulma. Länsi-Suomen taloudellinen tutkimuslaitos. Julkaisuja 70.

Relph. E. (1976) Place and Placelessness. London: Pion Limited.

Sennet, R. (1999) Growth and Failure: The New Political Economy and Its Culture. In Featherstone, M. \& Lash, S. (eds.) Spaces of Culture. City, Nation, World. London: Sage, pp. 14-27.

Soja, E. (1989) Postmodern Geographies. The Reassertion of Space in Critical Social Theory. London: Verso.

Soja, E. (1996) Thirdspace. Journeys to Los Angeles and Other Real-and-Imagined Places. Massachusetts: Blackwell.

Tervo; H. (1997) Long-distance Migration and Labour Market Adjustment: Empirical Evidence from Finland 1970-1990. Jyväskylän yliopisto, taloustieteen laitos, Working Papers 168.

Thrift, N. (1996) Spatial Formations. London: Sage. 